\title{
Vikipediyada konfliktli məqalələrin avtomatik aşkarlanması metodu
}

\author{
Rasim Oliquliyev $^{1}$, Tofiq Kazımov ${ }^{2}$ İradə Oləkbərova ${ }^{3}$ \\ AMEA İnformasiya Texnologiyaları İnstitutu, Bak1, Azərbaycan \\ ${ }^{1}$ directorliit.science.az, ${ }^{2}$ tofigeiit.science.az, ${ }^{3}$ airada.09@gmail.com
}

\begin{abstract}
Xülaso- Vikipediya virtual ensiklopediyasında mövcud problemlər təsnifatlandırılmış, mübahisəli məqalələri şərtləndirən amillər müəyyənləşdirilmişdir. Konfliktli məqalələri aşkar etmək üçün konfliktlik əmsalının hesablanması təklif olunmuşdur. Hesablamada "silib-bərpa etmək" əməliyyatı, şərhlər, redaktələr və hiperistinadların sayı nəzərə alınmışdır.
\end{abstract}

Açar sözlor- Vikipediya, konfliktli moqalolor, "silib-borpa etmok” ’moliyyatı, informasiya qarşıdurması, loq-fayl, müzakiro sohifosi.

\section{GİRIŞ}

Dünyada ən nəhəng informasiya mənbəyi olmaqla, həm də sosial şəbəkənin imkanlarına malik olan Vikipediya virtual ensiklopediyası və onun layihələrinin bu günkü müvəffəqiyyəti sübut etdi ki, müasir dövrdə İnternet istifadəçiləri virtual mühitin passiv istifadəçiləri olmaq istəmirlər, onlar bilik və bacarıqlarını dünya ictimaiyyətinə göstərmək, vitual mühitin bir hissəsi olmaqla dünyada gedən sosial və siyasi proseslərdə fəal iştirak etmək arzusundadirlar [1].

Vikipediya genişləndikcə bu şəbəkə vasitəsilə dünyanın istənilən nöqtəsində yaşayan insanlarla virtual ünsiyyət qurmaq, müzakirələr aparmaq, tarixi və gündəlik hadisələr haqqında məlumatlar əldə etmək mümkündür. Sosial medianın istiqamətlərindən biri olan Vikipediya İnternet istifadəçiləri arasında əməkdaşlığın yeni forması - vikicəmiyyətin (Wiki Community) yaranmasına səbəb olmuşdur [2, 3]. Vikipediyanın normal fəaliyyəti bir istifadəçinin yaratdığ 1 ensiklopedik məqalənin digər istifadəçilər tərəfindən əlavə kontent daxil etdirilərək zənginləşdirilməsi üzərində qurulmuşdur [3, 4]. Kollektiv iş prosesində istifadəçilər bir-birlərinin səhvlərini düzəltməklə mükəmməl məqalənin ərsəyə gəlməsinə nail olurlar. Lakin müşahidələr göstərir ki, ensiklopedik məqalələr üzərində kollektiv fəaliyyət bəzən konfliktlərə və informasiya qarşıdurmalarına səbəb olur [5].

Viki-mühitlə bağlı yeni tendensiyalar bir dövlətin digər dövlətin sosial həyatına, vətəndaşlarının informasiya mühitinə təsirində böyük imkanlar yaratmaqdadır. $\mathrm{Bu}$ səbəbdən bir çox qabaqcıl dövlətlər viki texnologiyalarının imkanlarını dərindən öyrənərək onlardan öz siyasi və iqtisadi məqsədləri üçün istifadə etməkdədirlər. Eyni zamanda viki-mühitin cəmiyyətin bilik daşıyıcılarını özünə cəlb etməsi və insanların öz əmək və biliklərini, vaxtlarını təmənnasız olaraq viki-layihələr vasitəsilə dünya ictimaiyyətinə bağışlamaq istəməsi alimləri düşündürməkdədir [6-9].

Tədqiqatda məqsəd konfliktli məqalələrin aşkarlanması və onları təsadüfi səhvlər və mübahisələrin olduğu məqalələrdən fərqləndirməkdir.

\section{VİKİPEDIYYADA MÖVCUD PROBLEMLӘR HAQQINDA}

Araşdırmalar göstərir ki, viki-mühitdə toplanan məlumatların mövzusu onu yaradan istifadəçilərin biliyini, dünya görüşünü və daşıdığı ideologiyanı əks etdirir [10]. Viki-cəmiyyət üzvləri viki-səhifələrə tələb olunan informasiyanı deyil, şəxsən onları maraqlandıran və ya yaxş1 bildikləri sahələrlə əlaqədar məlumatları daxil etməyə üstünlük verirlər. Bu xüsusiyyət viki-səhifələrdə informasiyanın həcminə, aktuallı̆̆ına, keyfiyyətinə təsir göstərir və informasiya tutumuna, keyfiyyətinə görə vikisəhifələr arasında kəskin fərq yaradır [11]. Vikipediyanın malik olduğu geniş imkanlar viki-mühitdə müxtəlif mənfi amillərin ortaya çıxmasına şərait yaradır. $\mathrm{Bu}$ amillərə aşağıdakılar aiddir [12]:

- viki-səhifələrə müraciətdə hər hansı məhdudiyyət mexanizminin olmaması nəticəsində vandalizm hallarının mövcudluğu;

- MediaWiki əsasında yaradılmış səhifələrdə hədsiz dərəcədə çox hiperistinadların olması və onlardan müəyyən hissəsinin tam olmayan və ya ümumiyyətlə mövcud olmayan səhifələrə keçidin olmasi;

- istifadəçilərə redaktə azadlığı verən viki-mühitdə müəyyən qarışıqlığın, sistemliyin pozulması hallarının mövcudluğu.

- viki-səhifələrdə informasiya-psixoloji təsir, redaktələr müharibəsi və $\mathrm{s}$. əməliyyatların mövcudluğu və s.

Viki-mühitdə istifadəçilərin fəaliyyəti müxtəlif vəziyyətdə ola bilər, məsələn, əməkdaşlıq, rəqabət, 
inteqrasiya və qarşı1durma [3, 9]. Hər bir növ fəaliyyətin analizi viki-mühitdə hadisələrin gələcək inkişafını proqnozlaşdırmağa imkan yaradır. Ensiklopedik məqalələr üzərində baş verən bütün dəyişikliklər və bu dəyişiklikləri həyata keçirən istifadəçilər haqqında məlumatlar vikisəhifənin loq-faylında saxlandığı və İnternet istifadəçilərinə əlyetərli olduğu üçün müxtəlif istiqamətdə tədqiqatlarda onlardan geniş istifadə olunur [12-15].

Vikipediyada ensiklopedik məqalələrin kollektiv hazırlanması və redaktə olunması bir çox hallarda fikir ayrılığına, istifadəçilər arasında bu və ya digər mövzu ətrafinda mübahisələrin yaranmasına və bu mübahisələrin informasiya qarşıdurmalarına keçməsinə səbəb olur. Belə qarşıdurmalar çox zaman məqalədə edilən dəyişikliklərin geri qaytarılmasına və məqalənin köhnə variantının bərpa edilməsinə və qarşı tərəfin narazılığına səbəb olur.

Viki-cəmiyyət konfliktli situasiyaların aradan qaldırılması üçün Vikipediya layihəsində müxtəlif qaydalar sistemi yaradılmışdır. Bu qaydalara redaktələr müharibəsi (Edit warring) [16], mübahisə yaradan məqalələrin müxtəlif şablonlar vasitəsilə siyahıya alınması və redaktələrə məhdudiyyətin qoyulması (Protection policy) [17], konflikt yaradan istifadəçilərin bloklanması (Blocking policy) [18] və s. aiddir. Qaydalar viki-texnologiyaların "hər bir İnternet istifadəçisinin viki-səhifələri redaktə etmə hüququna malik olması" prinsipini pozsa da viki-mühitdə qarşıdurmaların qarşısını almaq üçün digər alternativ yol hələ ki, tapılmayıbdır.

\section{MӘQALӘNIN MÜBAHİSӘLİ OLMASINI ŞӘRTLONDIRON AMILLOR}

İstifadəçinin Vikipediya və onun layihələrində etdiyi bütün dəyişikliklər server tərəfindən qeydə alınır və bu haqda loq-faylda yazı yaranır. Vikipediyada server tərəfindən qeydə alınan ümumi loq-fayl və eyni zamanda hər bir viki-səhifənin fərdi loq-faylı mövcuddur. Vikimühitdə serverin loq-faylından fərqli olaraq viki-səhifələrin loq-faylı bütün İnternet istifadəçiləri üçün açıqdır və burada aşağıdakı göstəriçilər verilir:

- istifadəçinin müraciət etdiyi viki-səhifənin adi;

- qeydiyyatdan keçmiş istifadəçinin qeydiyyat adı;

- anonim istifadəçinin İP ünvanı;

- viki-səhifədə edilən dəyişikliyin tarixi və vaxtı;

- daxil edilən və ya silinən informasiyanın baytlarla həcmi;

- viki-səhifənin əvvəlki variantlarla müqayisəsi;

- edilən dəyişikliyin xarakteri.

$\mathrm{Bu}$ göstəricilərdən və viki-səhifələrdə saxlanılan mətn tipli məlumatlardan istifadə etməklə konfliktə səbəb olan ensiklopedik məqalələri müəyyən əlamətlərə görə təyin etmək mümkündür:

Nüfuzlu mənbələrə istinada görə analiz. Vikipediya qaydalarına əsasən ensiklopedik məqalədə informasiyanın düzgünlüyünü sübut etmək üçün ilk növbədə nüfuzlu mənbələrə (elmi və siyasi mühitdə etibarlı hesab olunan elmi jurnallar, kitablar, mötəbər xəbər agentlikləri, rəsmi dövlət saytları və s.) istinad etmək tələb olunur [16].

Ensiklopedik məqalənin informasiya təsirini artırmaq üçün və ya informasiya qarşıdurması zamanı viki- istifadəçilər daxil etdikləri informasiyanın düzgün olduğunu sübut etmək üçün çoxlu sayda mötəbər mənbələrə istinadlar daxil etməyə məcburdurlar. Nəticədə informasiya qarşıdurmasına səbəb olan məqalələrdə istinadların sayı digər məqalələrə nisbətən daha çox olur. $\mathrm{Bu}$ əlamətə görə mübahisəli məqalələri təyin etmək mümkündür. Lakin nəzərə almaq lazımdır ki, geniş mövzunu əhatə edən, lakin mübahisə yaratmayan vikisəhifələrə də bəzi hallarda həddən artıq çox sayda istinadlar daxil edilir. Çox sayda hiperistinadların mübahisəli olmayan viki-səhifələrə də daxil olma ehtimalını nəzərə alaraq, tədqiqatımızda mübahisəli məqalələrin aşkarlandırılması üçün digər göstəricilərin də nəzərə alınması vacibdir.

Ensiklopedik maqalanin müzakira sahifasina göra analiz. Ensiklopedik məqalənin müzakirə səhifəsinin həcmi mübahisəli və konfliktli vəziyyəti aşkarlamaq üçün yaxşı indikator ola bilər. Belə ki, viki-səhifələrdə konflikt nə qədər kəskindirsə müzakirə səhifəsinin həcmi bir o qədər böyükdür. Sosial şəbəkələrdə olduğu kimi, hər bir ensiklopedik məqalənin müzakirə səhifəsində bütün istifadəçilər iştirak edə bilər: administratorlar, yeni istifadəçilər və hətta anonimlər. Lakin sosial şəbəkələrdən fərqli olaraq viki-mühitdə yalnız ensiklopedik məqalələrin mövzusu ətrafında müzakirələrə icazə verilir. Şəxsi və əyləncə xarakterli mövzular ətrafinda müzakirələr aparmaq qadağandır [19]. Müzakirə səhifələrinin loq-fayllarından istifadə etməklə müzakirələrin nə zaman və kim tərəfindən aparıldığını təyin etmək mümkündür [9].

Müzakirə səhifələrində hər bir şərhin sonunda istifadəçinin imzasının qoyulması vacibdir. Müzakirə səhifələrində ensiklopedik məqalələrdən fərqli olaraq müəllifin yazdığ 1 şərhin axırında imza və tarix qoyulduğu üçün müəllifin müəyyən olunması asandır. Müzakirə səhifələri mübahisəli məsələlərin həllində konsensus əldə olunmasına şərait yaradır və konfliktləri həll etmək üçün nəzərdə tutulmuşdur. Lakin çox zaman gözlənilənlərin əksinə olaraq, müzakirə səhifələri çoxlu sayda istifadəçiləri və qrupları cəlb edən informasiya qarşıdurması meydanına çevrilir $[1,9]$.

Konfliktli məqalənin müzakirə səhifəsinin həcmi orada yazılan şərhlərin hesabına həddən artıq çoxalır və müzakirə predmeti olan ensiklopedik məqalənin həcmindən xeyli böyük olur. Viki-mühitdə müzakirə səhifəsinin həcminin ensiklopedik məqalənin həcmindən böyük olması anomal haldır və təcrübə göstərir ki, adətən mübahisəli məlumatlar olan viki-səhifələrdə bu vəziyyət yarana bilər.

Ensiklopedik maqalanin adının dayişdirilməsinə görə analiz. Məqalənin adının dəyişdirilməsinin müxtəlif səbəbləri vardır və onlar əsasən aşağıdakılardır:

- Məqalənin adı mövzunu əhatə etmədikdə və ya dəqiq olmadıqda;

- Məqalənin adında qrammatik və ya orfoqrafik səhv olduqda;

- Məqalənin adı qərəzli və neytrallıq prinsiplərini pozduqda;

- Eyni və ya oxşar adda məqalə mövcud olduqda.

Müşahidələr göstərir ki, konfliktli məqalələrdə vikisəhifənin adının bir neçə dəfə dəyişdirilməsi ehtimalı çox böyükdür. 
"Neytrallıq" şablonuna görə analz. Ensiklopedik məqalədəki mövcud kontent mübahisə və ya qarşıdurma yaradırsa həmin viki-səhifəyə mövcud kontentin Vikipediyanın neytrallıq prinsiplərini pozması haqqında xüsusi şablon daxil edilir (şəkil 1).

The neutrality of this section is disputed. Relevant discussion may be found on the talk page. Please do not 5. remove this message until conditions to do so are met. (October 2017) (Learn how and when to remove this template message)

Şəkil 1. Məqaləyə daxil edilən kontentin neytrallıq prinsiplərini pozmasını bildirən şablon

Şablon ensiklopedik məqalədəki informasiyanın düzgünlüyünün şübhəli olması ilə əlaqədar oxucuları xəbərdar edir. Həmçinin, bu tip viki-səhifələrin xüsusi siyahıya daxil etmə funksiyasını daşıyır. Siyahıda şablon daxil edilmiş bütün ensiklopedik məqalələrin adları verilir.

"Silib-barpa etmək" amoliyyatlarının sayına görə analiz. Viki-mühitdə informasiya qarşıdurmasını və mübahisəli vəziyyəti aşkarlamaq üçün təklif olunan digər yanaşma - viki-səhifənin loq-faylında verilmiş göstəricilərin analizinə əsaslanır. Səhifələrin loqfayllarında viki-istifadəçilərin fəaliyyətlərini zamana və daxil etdikləri və ya sildikləri informasiyanın həcminə görə analiz etmək, həmçinin, loq-faylları analiz etməklə vikisəhifədə edilən dəyişikliklərin ləğv olunması ilə əlaqədar anomal halları da təyin etmək mümkündür [20].

Vikipediyanın ümumi qaydalarına əsasən viki-səhifələr ətrafında tez-tez baş verən informasiya qarşıdurmalarının qarşısını almaq üçün ensiklopedik məqalədə bir gündə 3 və daha çox "silib-bərpa etmək" əməliyyatı keçirilsə, həmin məqalə "3 redaktə qaydası"na (The three-revert rule) görə konfliktli məqalə hesab olunur və administratorlar tərəfindən nəzarətə götürülür [16]. Ensiklopedik məqalələrdə "silib-bərpa etmək" əməliyyatlarının dinamikliyi zamandan asılı olaraq dəyişir. Tədqiqatlar göstərir ki, bu əməliyyatlar viki-mühitdə informasiya qarşıdurmalarının yaranmasına səbəb olan əsas amillərdəndir [21].

Vikipediya administratorları hər hansı məqalə üzərində “silib-bərpa etmək" əməliyyatlarının qarşısını almağa (vikisəhifələrdə dəyişikliklər edilməsi məhdudlaşdırılır, qarşıdurma yaradan istifadəçilərə xəbərdarlıq edilir və ya onlar bloklanır) çalışsalar da, problemi tam nəzarətdə saxlamaq mümkün deyil.

\section{KONFLIKKTLIKK ӘMSALI}

Vikipediyada ensiklopedik məqalələr məlumatların həcminə, istinad olunan mənbələrin sayına, keyfiyyətinə, strukturuna və s. əlamətlərə görə fərqlənirlər. Fərqləndirici əlamətlərdən biri də məqalədəki redaktələrin sayıdır. Mübahisəli və konfliktli məqalələrdə redaktələrin sayı, "silib-bərpa etmək" əməliyyatlarının, şərhlərin və hiperistinadların sayı digər neytral məqalələrlə müqayisədə daha çoxdur. Belə olan halda, mübahisəli məqalələrin aşkarlanmasında aşağıdakı şərtləri ödəyən ensiklopedik məqalələrdən istifadə oluna bilər:

1) $t w p_{i}>w p_{i}-$ müzakirə səhifəsinin həcmi $\left(t w p_{n}\right)$ məqalənin öz həcmindən $\left(w p_{n}\right)$ daha böyük olur;

2) $r w p_{i}>3$ - "Silib-bərpa etmək" əməliyyatlarının sayı 3-dən çox olmalıdır.

Yuxarıda göstərilən hər iki şərt ödənilərsə, məqalə mübahisəli hesab oluna bilər. Lakin konfliktli məqalələrlə mübahisəli məqalələr arasında fərq olduğundan konfliktə səbəb ola biləcək məqalələri aşkarlamaq üçün göstərilən şərtlər yetərli deyil. Məsələn, elmi mövzularda yazılan məqalələr ətrafinda da sağlam mühitə xələl gətirməyən mübahisələr ola bilər ki, bunların informasiya qarşıdurması və ya konfliktli situasiya kimi qəbul edilməsi düzgün olmaz.

Tədqiqatımızda konfliktə səbəb olan məqalələri aşkar etmək üçün aşağıdakı göstəricilərdən istifadə etmək nəzərdə tutulubdur:

1) $P_{i}$ sənədində redaktələrin ümumi sayı $-r p_{i}$, burada ensiklopedik məqalədənin loq-faylından redaktələrin sayını təyin etmək mümkündür;

2) $P_{i}$ sənədində (viki-səhifə) "silib-bərpa etmək" əməliyyatının sayı - $r w p_{i}$;

3) Müzakirə səhifəsində şərhlərin sayı - $t p_{i}$; şərhlərin sayı hər bir şərhin altında qoyulan imzaların sayına görə müəyyənləşdirilir.

4) Ensiklopedik məqalədə mənbəyə istind edən hiperistinadların sayı $-h p_{i}$.

Redaktələrin ümumi sayı $r p_{i}$, hər zaman digər göstəricilərdən böyük olduğuna görə aşağıdakı şərt ödənməlidir:

$$
r w p_{i}<r p_{i} ; t p_{i}<r p_{i} ; h p_{i}<r p_{i}
$$

Məqalənin konfliktlik əmsalını hesablamaq üçün aşağıda verilmiş düsturlardan istifadə olunur:

1) "Silib-bərpa etmək" əməliyyatının məqalədə neçə dəfə yerinə yetirildiyinə əsaslanan konfliktlik əmsali:

$$
\begin{gathered}
\mathrm{C}_{1 i}=\frac{r w p_{i}}{r p_{i}}, i=1, \ldots, n ; \\
0 \leq \mathrm{C}_{1 i} \leq 1
\end{gathered}
$$

2) Müzakirə səhifəsində şərhlərin sayına görə konfliktlik əmsalı:

$$
\begin{gathered}
\mathrm{C}_{2 i}=\frac{t p_{i}}{r p_{i}}, i=1, \ldots, n ; \\
0 \leq \mathrm{C}_{2 i} \leq 1
\end{gathered}
$$

3) Hiperistinadların sayına görə konfliktlik əmsalı:

$$
\begin{aligned}
\mathrm{C}_{3 i} & =\frac{h p_{i}}{r p_{i}}, i=1, \ldots, n ; \\
0 & \leq \mathrm{C}_{3 i} \leq 1
\end{aligned}
$$

Ümumi şəkildə konfliktlik əmsalı belə hesablanacaqdır:

$$
\begin{gathered}
\mathrm{C}_{u i}=\prod_{j=1}^{3} C_{j i}=C_{1 i} \cdot C_{2 i} \cdot C_{3 i}=\frac{r w p_{i} \cdot t p_{i} \cdot h p_{i}}{r p_{i}{ }^{3}}, i=1, \ldots, n ; \\
0 \leq \mathrm{C}_{u i} \leq 1
\end{gathered}
$$

Misal olaraq Vikipediyanın ingilis dilli seqmentindən Azərbaycanla bağli 8 məqalə seçilib və bu məqalələrin konfliktlik əmsalının hesablanması tələb olunur. Məqalələrin redaktələrin sayına, "silib-bərpa etmək" 
əməliyyatına, şərhlərin sayına və hiperistinadların sayına görə konfliktlik əmsalları hesablanır (Cədvəl 1).

Konfliktlik əmsallarının hasili tapılır və müqayisə olunur. Diaqramdan göründüyü kimi "Sumgait pogrom” və "Ramil Safarov" məqalələri daha çox konfliktlik əmsalına malikdirlər (şəkil 2). Buradan da müəyyən etmək olar ki, bu məqalələr Vikipediyanın ingilis dilli seqmentində daha tez-tez informasiya qarşıdurmalarına səbəb olurlar. "Astara" və "Kura" məqalələri mübahisəli məqalələr üçün verilən şərtləri ödəmədiklərinə görə konfliktlik əmsalı digər mübahisəli məqalələrlə müqayisədə daha kiçikdir.

\section{CəDVӘL 1. MӘQALӘLӘRIN KONFLIKTLİK ӘMSALI}

\begin{tabular}{|c|c|c|c|c|c|c|c|}
\hline $\begin{array}{c}\text { Viki- } \\
\text { sahifalar }\end{array}$ & $r p_{i}$ & $r w p_{i}$ & $t p_{i}$ & $h p_{i}$ & $C_{1 i}$ & $C_{2 i}$ & $C_{3 i}$ \\
\hline Stepanakert & 1301 & 62 & 143 & 38 & 0,05 & 0,10 & 0,03 \\
\hline $\begin{array}{c}\text { Kirovabad } \\
\text { pogrom }\end{array}$ & 291 & 25 & 16 & 17 & 0,06 & 0,04 & 0,04 \\
\hline $\begin{array}{c}\text { Ramil } \\
\text { Safarov }\end{array}$ & 1029 & 56 & 194 & 99 & 0,05 & 0,19 & 0,10 \\
\hline Astara & 334 & 4 & 2 & 8 & 0,01 & 0,01 & 0,02 \\
\hline $\begin{array}{c}\text { Sumgait } \\
\text { pogrom }\end{array}$ & 706 & 47 & 86 & 83 & 0,07 & 0,12 & 0,12 \\
\hline $\begin{array}{c}\text { Khojaly } \\
\text { massacre }\end{array}$ & 2812 & 102 & 1378 & 88 & 0,04 & 0,05 & 0,03 \\
\hline Kura & 320 & 1 & 12 & 24 & 0,003 & 0,04 & 0,08 \\
\hline Shusha & 1991 & 52 & 1031 & 110 & 0,03 & 0,05 & 0,06 \\
\hline
\end{tabular}

Hesablamaların nəticələri əsasında yalnız $0,0001<\mathrm{C}_{u i}<1$ şərtini ödəyən məqalələrin konfliktli məqalə kimi qəbul edilməsi qərara alınmışdır.

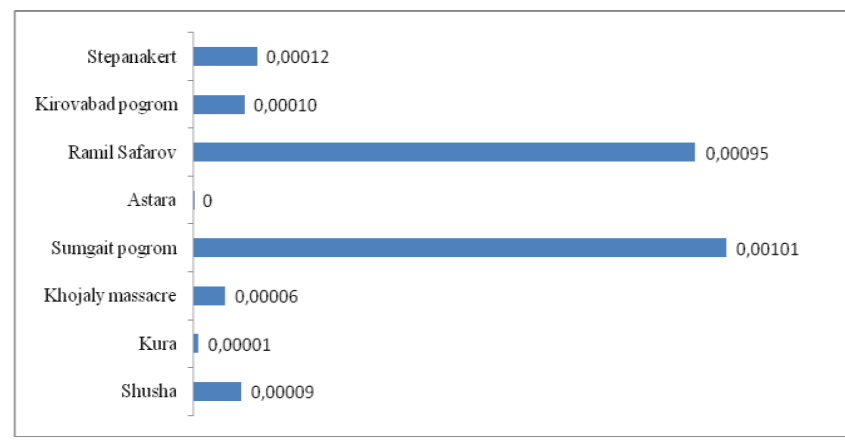

Şəkil 2. Ensiklopedik məqalələrin konfliktlik əmsalına görə müqayisəsi

Təklif olunan metodun eksperimental yoxlanmas zamanı viki-mühitdə mövcud olan hər bir ensiklopedik məqaləyə müəyyən rəqəmlərdən ibarət kod verilir. Hər bir mübahisəli məqalənin konfliktlik əmsalı hesablanır. Konfliktlik əmsalının hansı məqaləyə aid olmasını müəyyən etmək üçün kodlardan uyğun məqalələrə hiperkeçidlər verilir. Yalnız konfliktlik əmsalı 0,0001-dən böyük olan ensiklopedik məqalələr informasiya qarşıdurmasına səbəb olan konfliktli məqalələr siyahısına daxil edilir.

\section{NəTİCə}

Araşdırmalardan məlum oldu ki, viki-mühitdə mübahisəli məqalələri aşkarlamaq üçün müxtəlif əlamətlərdən istifadə edilir. Bunlara nüfuzlu mənbələrə istinad, ensiklopedik məqalənin müzakirə səhifəsinin həcmi, məqalənin adının dəyişdirilməsi, neytrallığın pozulması ilə bağlı şablonunun daxil edilməsi və "silibbərpa etmək" əməliyyatları daxildir. Həmçinin məlum oldu ki, bu əməliyyatlar mübahisəli məqalələri aşkarlasalar da, konfliktli məqalələrin aşkarlanması üçün yetərli deyillər.

Konfliktli məqalələri aşkarlamaq üçün məqalənin mübahisəli olmasını şərtləndirən əlamətlərdən konpleks istifadə nəzərdə tutulmuşdur. Verilən göstəricilər əsasında məqalənin konfliktlik əmsalı hesablanmışdır. Konfliktlik əmsalı yüksək olan məqalələrin analizi viki-mühitdə informasiya qarşıdurmalarının, ensiklopedik məqalələrin keyfiyyətinin, gizli sosial şəbəkələrin aşkarlanması və s. məsələlərin həllində, həmçinin müxtəlif müəssisələrdə və dövlət təşkilatlarında qərarların qəbulunda istifadə oluna bilər.

\section{ӘDӘВİYYAT}

[1]. W. Christian. Wiki: A technology for conversational knowledge management and group collaboration // Journal of the Communications of the Association for Information Systems, 2004, vol. 13 , no. 2 , pp. $265-289$.

[2]. İ.Y. Oləkbərova. E-dövlətin formalaşmasinda viki-cəmiyyətin rolu // İnformasiya cəmiyyəti problemləri, 2014, №2(4), səh. 18-28.

[3]. L. Alfaro, A. Kulshreshtha, I. Pye, B.T. Adler Reputation systems for open collaboration // Communications of the ACM, 2011, vol. 54, no. 8 , pp. 81-87.

[4]. B. Leuf, W. Cunningham. The Wiki Way: quick collaboration on the Web, PA: Addison-Wesley, 2001, 200 p.

[5]. R. Sumi, T. Yasseri, A. Rung, A. Kornai, J.Kertesz. Edit wars in Wikipedia / Proceedings of the International Confernece on Social Computing, IEEE, New York, 2011, pp. 724-727.

[6]. H. Meishar-Tal, E. Tal-Elhasid. Measuring collaboration in educational wikis - amethodological // International Journal of Emerging Technologies in Learning, 2008, vol. 3, pp. 46-49.

[7]. R. Mihalcea, A. Csomai. Wikify!: linking documents to encyclopedic knowledge / Proceedings of the 17th ACM Conference on Conference on Information and Knowledge Management, New York, April 22-27, 2007, pp. 233-242.

[8]. S. Javanmardi, W. David. McDonald, Lopes V. Vandalism detection in Wikipedia / Proceedings of the 7th International Symposium on Wikis and Open Collaboration, New York, USA, Oct. 2011. ACM Press., pp. 82.

[9]. S. Javanmardi, C. Lopes, P. Baldi. Modeling user reputation in wikis // Journal of Statistical Analysis and Data Mining, 2010, vol. 3 no. 2, pp. 126-139.

[10]. U. Cress, J. Kimmerle A systemic and cognitive view on collaborative knowledge building with wikis // International Journal of Computer-Supported Collaborative Learning, 2008, vol. 3, no. 2, pp. $105-122$.

[11]. R.M. Alguliyev, R.M. Aliguliyev, I.Y. Alakbarova. Extraction of hidden social networks from wiki-environment involved in information conflict // International Journal of Intelligent Systems and Applications (IJISA), 2016, vol. 8, no. 2, pp. 20-27.

[12]. İ.Y. Oləkbərova. Semantik MediaWiki proqramının imkanları haqqinda / "Proqram mühəndisliyinin aktual elmi-praktiki problemləri" I Respublika konfrans1, 2017, səh. 54-56.

[13]. B. T. Adler, L. Alfaro, S.M. Mola-Velasco, P. Rosso, A.G. West. Wikipedia vandalism detection: combining natural language, metadata and reputation features / Proceedings of the $12^{\text {th }}$ International Conference on Intelligent Text Processing and Computational Linguistics, 2011, pp. 277-288.

[14]. B. T. Adler, L..Alfaro, I. Pye. Detecting Wikipedia vandalism using WikiTrust / Lab Report for PAN at CLEF, 2010, pp. 22-23.

[15]. Peacock T., Fellows G., Eustace K. The quality and trust of wiki content in a learning community / Proceedings of the 24th Annual 
ASCILITE Conference, Singapore, December 2-5, 2007, pp. 822832.

[16]. https://en.wikipedia.org/wiki/Wikipedia:Edit_warring

[17]. https://en.wikipedia.org/wiki/Wikipedia:Protection_policy

[18]. https://en.wikipedia.org/wiki/Wikipedia:Blocking_policy

[19]. https://en.wikipedia.org/wiki/Help:Talk_pages

[20]. https://en.wikipedia.org/wiki/Help:Reverting

[21]. T. Yasseri, R. Sumi, A. Rung, A. Kornai, J. Kertész. Dynamics of conflicts in Wikipedia // PLoS ONE, 2012, vol 7, no. 6, http://arxiv.org/pdf/1202.3643v2.pdf

\section{METHOD OF AUTOMATIC DETECTION OF} CONFLICTING ARTICLES IN WIKIPEDIA

Alguliev R.M. ${ }^{1}$, Kazimov T. Kh. ${ }^{2}$, Alakbarova I.Y. ${ }^{3}$

${ }^{1,2,3}$ Institute of Information Technology of ANAS, Baku, Azerbaijan

Idirector@iit.science.az, ${ }^{2}$ tofig@iit.science.az,

3airada.09@gmail.com

Abstract - The Wikipedia articles on controversial current issues in virtual Encyclopedia categorized and contributing factors identified. It was suggested that the coefficients of conflict to detect conflicting articles. The calculation "delete and restore" process, interpretation, regulations and hyperlinks contains the number.

Keywords - wikipedia, conflict articles, "delete and restore" operation, information confrontation, log file, discussion page. 